\title{
A PROSPECTIVE STUDY OF SCALPEL SKIN INCISION VERSUS DIATHERMY IN PATIENTS UNDERGOING INGUINAL HERNIOPLASTY
}

\author{
Mahesh Gupta1, Sameer Soni², Pawan Saini \\ 1 Professor, Department of Surgery, Rama Medical College Hospital and Research Centre, Mandhana, Kanpur, Uttar Pradesh. \\ 2Senior Resident, Department of Surgery, Dr. Baba Saheb Ambedkar Hospital, Rohini, Delhi. \\ ${ }^{3}$ Senior Resident, Department of Surgery, Dr. Baba Saheb Ambedkar Hospital, Rohini, Delhi.
}

\section{ABSTRACT}

\section{BACKGROUND}

Electrocautery is mainly used for haemostasis and less often for skin incisions. We have done a prospective study to compare the postoperative complications regarding skin incisions made by scalpel and electrocautery in patients undergoing inguinal hernioplasty.

Aim- This study is done to evaluate and compare the post-operative pain at 6, 12 and 24 hours in electrocautery incision and scalpel incision over the skin and also to compare the incidence of surgical site infection in two different types of skin incisions on day 1 and day 7 .

\section{MATERIALS AND METHODS}

This study was conducted in 80 patients undergoing inguinal hernia repair who were admitted in the Department of General Surgery at Rama Medical College Hospital \& Research Centre, Mandhana, Kanpur. A prospective randomised control trial with double blinding was done. The patients were randomised in two groups: Group A 40 patients (Electrocautery) and Group B 40 patients (Scalpel).

\section{RESULTS}

The two groups formed by randomisation were statistically similar. The mean age of the patients under the Group-"Electrocautery Incision" was 46.20 years and under the Group-"Scalpel Incision" mean age of the patients was 46.85 years. In Group"Electrocautery Incision", the mean pain score at 6 hours was 6.53, at 12 hours it was 3.83 and at 24 hours it was 2.35 . Similarly, for the Group- "Scalpel Incision", the mean pain score at 6 hours was 6.63, at 12 hours it was 3.72 and at 24 hours it was 2.35 . There was no significant difference between the surgical site infection at day 1 and day 7 between the two groups.

\section{CONCLUSION}

Based on observations made in this study, it has been concluded that results of both groups that is Electrocautery Group and Scalpel Group are similar in relation to the post-operative pain and surgical site infection.

\section{KEYWORDS}

Scalpel, Skin Incisions, Electrocautery, Diathermy, Hernioplasty.

HOW TO CITE THIS ARTICLE: Gupta M, Soni S, Saini P. A prospective study of scalpel skin incision versus diathermy in patients undergoing inguinal hernioplasty. J. Evolution Med. Dent. Sci. 2017;6(39):3136-3138, DOI: 10.14260/Jemds/2017/676
BACKGROUND
Incision is made to gain access to the underlying structures ${ }^{1}$ whereas cauterisation is a medical term used to describe burning of the body tissues. Electrocautery (Diathermy) is used for tissue dissection; however, there is a fear of excessive scarring and poor wound healing which has curtailed its widespread use for skin incisions. Skin incisions are made with stainless steel scalpel, but these incisions are within cell matrix and the heat created disappears as steam, rather than being transferred to adjacent tissues. As electrode is moved forward, new cells come in contact and get vaporised with creation of incision. ${ }^{7}$ This explains subsequent healing with less scarring. Our study is done to compare any postoperative complications after skin incisions are made with scalpel and diathermy. supposed to be more painful with chances of wound infection and scarring in the postoperative period.2-6 The use of electrode in diathermy allows tissue cleavage without damage to the surrounding areas as this method heats cells

Financial or Other, Competing Interest: None.

Submission 08-04-2017, Peer Review 02-05-2017,

Acceptance 08-05-2017, Published 15-05-2017.

Corresponding Author:

Dr. Mahesh Gupta,

Professor, Department of Surgery,

Rama Medical College Hospital and

Research Centre, Mandhana,

Kanpur-209217, Uttar Pradesh.

E-mail: gm982003@yahoo.co.in

DOI: $10.14260 /$ jemds $/ 2017 / 676$

\section{MATERIALS AND METHODS}

This study was conducted in 80 patients undergoing inguinal hernia repair who were admitted in the Department of General Surgery at Rama Medical College Hospital \& Research Centre, Mandhana, Kanpur from September 2015 to May 2016. A prospective randomised control trial with double blinding was done in which the patients were randomised in two groups: Group A 40 patients (electrocautery) and Group B 40 patients (Scalpel). Randomisation was done by using a computer-generated number sequence and were contained in sequentially numbered opaque envelopes to ensure blinding. The observer was blinded to the type of incision used and gave his observation based on the predefined criteria. Informed consent was taken from the patients mentioning 
that the skin would be incised with either scalpel or electrocautery.

Sample size is taken as 40 each, for convenience without any calculation. All the cases of elective and uncomplicated inguinal hernia repair were included and bilateral inguinal hernia, immunocompromised, diabetic patients, chronic diseases like chronic kidney disease or hepatic disease, age more than 65 years or less than 16 years were excluded from the study. Post-operative pain at 6, 12 and 24 hours was observed in all the patients over the skin (Post-operative pain evaluation was stopped at $24 \mathrm{hrs}$. as patients were discharged after 24 hours on oral analgesics and next followed on $7^{\text {th }}$ day.). The incidence of surgical site infection in two different types of skin incisions was observed on day 1 and day 7. Statistical testing was conducted with the statistical package for the social science system version SPSS 17.0. Continuous variables were presented as mean $\pm \mathrm{SD}$, and categorical variables were presented as absolute numbers and percentage. The comparison of normally distributed continuous variables between the groups was performed using Student's t test. Nominal categorical data between the groups were compared using Chi-squared test or Fisher's exact test as appropriate. $\mathrm{P}<0.05$ was considered statistically significant.

\section{RESULTS}

The number of patients was equally divided among the two groups i.e. Electrocautery Incision (Group A - 40 patients) and Scalpel Incision (Group B- 40 patients) with the mean age of the patients under the group Electrocautery Incision was 46.20 years with standard deviation of 13.83 years whereas under the group Scalpel Incision, mean age of the patients was 46.85 years with standard deviation of 12.68 years. The correlation between the two groups among the various age groups was not significant. Under the group Electrocautery Incision, $97.5 \%$ of patients were male and $2.5 \%$ were female. However, under the Group-"Scalpel Incision", $100 \%$ of the patients were male (Table- 1) and the correlation between the two groups among the two sexes was not significant. The mean pain scores for the two groups were comparable and witnessed gradual decline over the 24-hour time period. For the Group-"Electrocautery Incision", the mean pain score at 6 hours was 6.53 with standard deviation of 0.60 , at 12 hours it was 3.83 with standard deviation of 0.75 and at 24 hours it was 2.35 with standard deviation of 0.53. Similarly, for the Group-"Scalpel Incision", the mean pain score at 6 hours was 6.63 with standard deviation of 0.63 , at 12 hours it was 3.72 with standard deviation of 0.75 and at 24 hours it was 2.35 with standard deviation of 0.48 (Table-2 ). The correlation between the two groups among the mean pain scores across the three different time points were not found to be significant during our analysis. The surgical site infection (SSI) at Day 1 between the two groups was observed as $5 \%$ in Group A and $2.5 \%$ in Group B with p value 1 and thus was insignificant (Table-3). SSI at Day 7 between the two groups was also insignificant with $2.5 \%$ patients suffering in Group A and 5\% suffering in Group B (Table -4).

\begin{tabular}{|c|c|c|c|c|c|}
\hline \multirow{2}{*}{ Sex } & \multicolumn{2}{|c|}{$\begin{array}{c}\text { Electrocautery } \\
\text { Incision } \\
\text { (Group A) }\end{array}$} & \multicolumn{2}{|c|}{$\begin{array}{c}\text { Scalpel } \\
\text { Incision } \\
\text { (Group B) }\end{array}$} & \multirow{2}{*}{$\begin{array}{c}\text { P } \\
\text { Value }\end{array}$} \\
\cline { 2 - 5 } & Frequency & $\mathbf{\%}$ & Frequency & $\%$ & \\
\hline Female & 1 & $2.5 \%$ & 0 & $0.0 \%$ & \\
\hline Male & 39 & $97.5 \%$ & 40 & $100.0 \%$ & \multirow{2}{*}{1.000} \\
\hline Total & $\mathbf{4 0}$ & $\mathbf{1 0 0 \%}$ & $\mathbf{4 0}$ & $\mathbf{1 0 0 \%}$ & \\
\hline Table 1. Comparison of Sex Distribution between \\
Electrocautery Incision and Scalpel Incision Group \\
\hline
\end{tabular}

\begin{tabular}{|c|c|c|c|c|c|}
\hline \multirow{2}{*}{$\begin{array}{c}\text { Pain } \\
\text { Score }\end{array}$} & \multicolumn{2}{|c|}{$\begin{array}{c}\text { Electrocautery } \\
\text { Incision } \\
\text { (n=40) } \\
\text { (Group A) }\end{array}$} & \multicolumn{2}{|c|}{$\begin{array}{c}\text { Scalpel } \\
\text { Incision } \\
\text { (n=40) } \\
\text { (Group B) }\end{array}$} & \multirow{2}{*}{ P Value } \\
\cline { 2 - 5 } & $\begin{array}{c}\text { Mean } \pm \\
\text { SD }\end{array}$ & $\begin{array}{c}\text { Min - } \\
\text { Max }\end{array}$ & $\begin{array}{c}\text { Mean } \pm \\
\text { SD }\end{array}$ & $\begin{array}{c}\text { Min - } \\
\text { Max }\end{array}$ & \\
\hline \multirow{2}{*}{6 Hours } & $\begin{array}{c}6.53 \pm \\
0.60\end{array}$ & $6-8$ & $\begin{array}{c}6.63 \pm \\
0.63\end{array}$ & $6-8$ & 0.468 \\
\hline 12 Hours & $\begin{array}{c}3.83 \pm \\
0.75\end{array}$ & $2-5$ & $\begin{array}{c}3.72 \pm \\
0.75\end{array}$ & $3-5$ & 0.552 \\
\hline 24 Hours & $\begin{array}{c}2.35 \pm \\
0.53\end{array}$ & $1-3$ & $\begin{array}{c}2.35 \pm \\
0.48\end{array}$ & $2-3$ & 1.000 \\
\hline
\end{tabular}

Table 2. Comparison of Pain Score at Different Time Points between Electrocautery Incision and Scalpel Incision Group

\begin{tabular}{|c|c|c|c|c|c|}
\hline \multirow{2}{*}{$\begin{array}{c}\text { SSI at } \\
\text { Day 1 }\end{array}$} & $\begin{array}{c}\text { Electrocautery } \\
\text { Incision } \\
\text { (Group A) }\end{array}$ & \multicolumn{2}{|c|}{$\begin{array}{c}\text { Scalpel } \\
\text { Incision } \\
\text { (Group B) }\end{array}$} & \multirow{2}{*}{$\begin{array}{c}\text { P } \\
\text { Value }\end{array}$} \\
\cline { 2 - 5 } & Frequency & $\mathbf{\%}$ & Frequency & $\%$ & \\
\hline No & 38 & $95.0 \%$ & 39 & $97.5 \%$ & \\
\hline Yes & 2 & $5.0 \%$ & 1 & $2.5 \%$ & \multirow{2}{*}{1.000} \\
\hline Total & 40 & $100 \%$ & 40 & $100 \%$ & \\
\hline \multicolumn{6}{|c|}{ Table 3. Comparison of SSI at Day 1 between } \\
Electrocautery Incision and Scalpel Incision Group \\
\hline
\end{tabular}

\begin{tabular}{|c|c|c|c|c|c|}
\hline \multirow{2}{*}{$\begin{array}{c}\text { SSI at } \\
\text { Day 7 }\end{array}$} & \multicolumn{2}{|c|}{$\begin{array}{c}\text { Electrocautery } \\
\text { Incision } \\
\text { (Group A) }\end{array}$} & \multicolumn{2}{c|}{$\begin{array}{c}\text { Scalpel } \\
\text { Incision } \\
\text { (Group B) }\end{array}$} & \multirow{2}{*}{$\begin{array}{c}\text { P } \\
\text { Value }\end{array}$} \\
\cline { 2 - 5 } & Frequency & $\mathbf{\%}$ & Frequency & $\%$ & \\
\hline No & 39 & $97.5 \%$ & 38 & $95.0 \%$ & \multirow{2}{*}{1.000} \\
\hline Yes & 1 & $2.5 \%$ & 2 & $5.0 \%$ & \\
\hline Total & $\mathbf{4 0}$ & $\mathbf{1 0 0} \%$ & $\mathbf{4 0}$ & $\mathbf{1 0 0 \%}$ & \\
\hline \multicolumn{6}{|c|}{ Table 4. Comparison of SSI at Day 7 between } \\
Electrocautery Incision and Scalpel Incision Group \\
\hline
\end{tabular}

\section{DISCUSSION}

Surgeons have been always in search of an ideal method of making a skin incision which would provide quick and adequate exposure with minimum loss of blood. Electrocautery is mainly used for haemostasis and less often for skin incisions. Earlier days when explosive anaesthetic agents were in use, electrosurgical instruments had limited use because of explosive risks associated with anaesthetic agents. After the invention of non-explosive anaesthetic agents like halothane, electrosurgical instruments like diathermy were increasingly used for tissue dissections except for skin incision. This reluctance for use of electrocautery is attributed to the belief that electrosurgical instruments cause devitalisation of tissue within the wound which consequently lead to wound infection and delayed wound healing. The fear of tissue 
injuries was first unfolded when this technique was used by Peterson in reconstructive and cosmetic faciomaxillary surgery, ${ }^{8}$ Mann and Klippel in paediatric surgery, ${ }^{9}$ Kamer in rhytidoplasty, ${ }^{10}$ Tabin in blepharoplasty, ${ }^{11}$ with minimum scarring and excellent results. Skin incisions with diathermy in general surgery was reported by Dixon and Watkin ${ }^{7}$ in patients undergoing inguinal herniorrhaphy and cholecystectomy. As mentioned above, various studies were undertaken to evaluate the efficacy of electrocautery over scalpel in making skin incision and results are varying. Some were showing better results with electrocautery, some showing similar results. In our study, 80 patients were randomised into two groups and incision was made with either scalpel or electrocautery depending on the allotted patient group. These patients were evaluated postoperatively for pain and wound complications and our study showed no difference between the two groups in postoperative pain and surgical site infection. The studies by Chrysos E et al, Kearns SR et al, Franchi $\mathrm{M}$ et al, Ali $\mathrm{Q}$ et al in the literature have not shown any significant difference in the wound infection rate and pain amongst the two groups. ${ }^{3,4,12,13}$ Hence, electrocautery and scalpel both can be used for making skin incision in inguinal hernioplasty.

\section{CONCLUSION}

The extent of tissue damage and risk of septic complications are not influenced by the diathermy electrode. On the contrary, it has been suggested that local tissue heating increases subcutaneous oxygen tension, thus enhancing the resistance of surgical wounds to infection. ${ }^{14}$ The results of this study are comparable with international studies and clearly support the use of electrocautery in performing skin incisions; however, this study is limited to a small sample size. The improper use of electrocautery may lead to decreased wound strength and devitalisation of tissues and the smart usage with correct frequency adjustment and training by manufacturer (as each company machine is unique) will definitely give better results than the scalpel skin incision.

\section{REFERENCES}

[1] Zinner MJ, Ashley SW. Maingot's abdominal operations. Chapter 4. $11^{\text {th }}$ edn. New York, McGraw Hill publication 2007:P 71.
[2] Chowdri NA, Wani NA, Ganai AA, et al. Comparative study of electrosurgical and scalpel incision in general surgery. IJS 2002;63:308-10.

[3] Kearns SR, Connolly EM, McNamara DA, et al. Randomised clinical trial of diathermy versus scalpel incision in elective midline laparotomy. BJS 2001;88(1):41-4.

[4] Chrysos E, Athanasakis E, Antonakakis S, et al. A prospective study comparing diathermy and scalpel incision in tension free inguinal hernioplasty. Am J Surg 2005;71(4):326-9.

[5] Pollinger HS, Mostafa G, Horold KL, et al. Comparison of wound healing characteristics with feedback circuit electrosurgical generators in a porcine model. Am J Surg 2003;69(12):1054-60.

[6] Sheikh B. Safety and efficacy of electrocautery scalpel utilisation for skin opening in neurosurgery. BJS 2004;18(3):268-72.

[7] Dixon AR, Watkin DF. Electrosurgical skin incision versus conventional scalpel: a prospective trial. FR Coll Surg Edinb 1990;35(5):299-301.

[8] Peterson A. The use of electrosurgery in reconstructive and cosmetic maxillofacial surgery. Dental clin North Am 1982;26(4):799-823.

[9] Mann W, Klippel CH. Electrosurgical skin incisions. J Paediatric Surg 1977;12:725-6.

[10] Kamer FM, Cohen A. High frequency needle dissection rhytidectomy. Laryngoscope 1985;95(9 Pt 1):1118-20.

[11] Tobin HA. Electrosurgical blepharoplasty: a technique that questions conventional concepts of fat compartmentalisation. Ann Plastic surg 1985;14(1):59-63.

[12] Moran RM, Blick M, Collura M. Double layer of transversalis fascia for repair of inguinal hernia: results in 104 cases. Surgery 1968;63(3):423-9.

[13] Ali Q, Siddique K, Mirza S, et al. Comparison of superficial surgical site infection following use of diathermy and scalpel for making skin incision in inguinal hernioplasty. Niger J Clin Pract 2009;12(4):371-4.

[14] Ikeda T, Tayefeh F, Sessler DI, et al. Local radiant heating increases subcutaneous oxygen tension. Am J Surg 1998;175(1):33-7. 